\title{
The Visual Language of Consumerism in Contemporary Artworks
}

\author{
Singgih Prio Wicaksono \& Anik Juwariyah \\ Arts and Cultural Education Department, Post Graduate Program \\ Universitas Negeri Surabaya \\ Jalan Ketintang, Surabaya 60231 \\ E-mail: singgih.18009@mhs.unesa.ac.id
}

Volume 6 Nomor 1 , April 2019: 56-62

\begin{abstract}
ABSTRAK
Bahasa Visual Konsumerisme dalam Karya Seni Kontemporer. Artikel ini mendeskripsikan wacana konsumerisme ketika dibahasakan secara visual dalam karya kontemporer. Penelitian ini bertujuan untuk mengetahui pendekatan visualnya, gaya ungkapannya, serta social effect dari karya-karya tersebut. Penelitian ini menggunakan pendekatan deskriptif dengan obyek kajian empat karya kontemporer dunia yang sangat terkenal, "Campbell's Soup Cans" karya Andi warhol, "Jesus Christ with Shopping Bags" kaya Banksy, "I Shop Therefore I Am" karya Barbara Kruger, "Super Supper" karya Ron English. Berdasarkan analisis terhadap empat karya tersebut dapat disimpulkan bahwa kecenderungan visual pada karya-karya tersebut adalah: (1) memiliki karakteristik visual bergaya Pop Art dengan penggunaan simbol-simbol budaya populer, (2) sarat akan unsur jenaka, satir dan sarkastik, (3) menimbulkan persoalan etis dan estetis.
\end{abstract}

Kata kunci: bahasa visual; konsumerisme; seni kontemporer

\begin{abstract}
This article describes how consumerism discourse is visualized in contemporary works with the aim to find out how the visual approach, how the style of expression, as well as the social effects of these works. Using a descriptive approach with the object of study of four world famous contemporary works, "Campbell's Soup Cans" by Andi warhol, "Jesus Christ with Shopping Bags" rich in Banksy, "I Shop Therefore I Am" by Barbara Kruger, "Super Supper" by Ron English. Based on the analysis of the four works, it can be concluded that the visual tendencies in these works are: (1) having visual characteristics of Pop Art style with the use of symbols of popular culture, (2) full of humorous, satirical and sarcastic elements, (3) giving rise to ethical and aesthetic issues.
\end{abstract}

Keywords: visual language; consumerism; contemporary art

\section{Introduction}

Starting with a classic question about what exactly is the function of art? From here then comes sharing answers to the determination of the function itself. Thanks to the function words, the genres in arts are established, such as Applied arts and Fine arts, a restriction that is now at last also starting to disappear because of the democratic discourse of contemporary art and heterogeneous. (Prambudi, 2016: 37). So what exactly is the function of art, from all the answers, there emerges an understanding that art is a form of communication, in visual art it is known as visual communication or visual language. Although this may seem abstract but in fact this is a logical concept, because basically before verbal language is used, humans have used drawing languages as found in cave drawings (Prambudi, 2016: 1).

Departing from this statement, art is actually a media that can be used to convey an idea or view, in this case an artist to the public through his artwork. What an artist wishes to convey is a true self-expression of what is observed and felt by them. This concerns an artist's empathy for a reality that is seen or felt, both concerning personal 
experiences and in the form of a response to a reality that he feels. (Wicaksono, 2018: 1). Furthermore, art can also be a very effective medium of information and even propaganda, in the context of contemporary culture, visual language plays an important role in influencing public perceptions and emotions through the symbols contained therein (Prambudi, 2016: 5). Therefore, in fact, a work of art is able to express something so deeply that it is even more communicative as well as provocative than verbal language.

Because of its communicative nature, through its visual language, art is then packaged in the form of art as a medium to criticize a social reality, such as capitalism and social inequality. In the world of visual arts, especially in the field of contemporary visual art, it is not uncommon for works to be created with the content of social criticism that is so clear and frontal, this tendency is characteristic of contemporary art (Ramadhani, 2017: 139). Contemporary artists realize that art must be able to voice injustice, inequality, confusion, suspicion and discourse about other realities, not merely to glorify visual beauty alone. At this point, the works which were laden with social criticism content was made, for example, the work of the most controversial British street artist today, Banksy. Where Banksy always includes political issues, humanity and social inequality in his work.

\section{Contemporary Artwork}

The message and content that is trying to be conveyed in a work is a manifestation of the awareness of concepts and ideas by an artist. Consciousness arising triggered by empathy for a reality he feels. It is at this point that an artist will cultivate his sense of sensitivity, realize his concept which was originally abstract into a representative visual sign. This is where awareness of that form is achieved, where an artist will choose what idiom will be used to describe his ideas into visual language. This understanding has actually been indirectly used by humans since prehistoric times. In those days, primitive people made cave images not only as imitating activities and merely denotative, but rather as connotative images. In the perspective of visual semiotics, primitive cave images are more meaningful as signs and symbols, not just as icons. (Djatiprambudi, 2016: 3).

Problems in the world of art creation are sometimes about what will be raised as the theme in the work itself. For centuries the trends that existed in the creation of works of art were duplication of natural and human objects in the perspective of beauty and perfection. But all of that collapsed instantly when Marcel Duchamp presented a place to urinate as his work entitled "Fountain", a time when views on art and aesthetics began to be questioned. Marcel Duchamp actually tries to convey that art is something that exists in humans and comes out as a form of expression. (Kusrini 2015: 117). Now as the discourse of contemporary visual art, artworks born as an interpretation of social reality, artists are beginning to try to interpret reality that is packaged in various idioms.

In the current context of reality, the view of reality itself has actually been much different as a result of the times and technology. What is called reality has now shifted to hyperreality, which is a situation in which physical and metaphysical realities overlap thanks to the world of hyperreality, a third world built from artificial reality. The world of hyperreality has changed almost all aspects of life to become more and more beyond reality. One form of social reality in the world of hyperreality is Posocial. Posocial is a form of social reality that exists in the form of substitution or its simulations, for example the social relations present on television or the internet (Piliang, 2004: 21). This kind of social reality is the one deconstruct the pattern of human life in the end, one of which is in the economic field, where the principle of economics is built excessively and extensively to encourage humans to race against each other in consumption (Piliang, 2004: 115).

This phenomenon of consumption culture is hereinafter referred to as consumerism, which is a tendency for people to consume excessively on impulses of prestige and lifestyle. The consumer community carries out consumption activities not only to spend the use value of an item, but to communicate certain meanings. For example someone uses expensive jewelry to mark his wealth 
and social status. In this kind of relationship, the consumer society controls objects as tools in the signaling and social communication process. (Piliang, 2003: 148)

Furthermore, consumerism is a culture, in which various forms of lies, illusions, hallucinations, dreams, artificiality, superficiality, surfaces are packaged in the form of commodities through hypersemiotic and imagological strategies which are then socially constructed through economic communication (advertisements, shows and so on) as the strength of the sign (semiotic power) so as to form self-awareness that is actually false. Thus the real consumption activities of consumer society is a sign language and the language of images. (Piliang, 2003: 60)

Given the discourse related to consumerism above, the question is then how can this discourse be realized through contemporary art? This question has actually been answered when looking at works that show criticism of consumerism itself, for example Andi Warhol's iconic work "Campbell's Soup Cans". At first glance there is no problem in the pictorial painting of tomato soup cans, but if it is truly understood, this work conveys how mass industrial power can destroy the present economic and social reality, a picture that is actually so clear but satirical.

At this point, it can actually be concluded that visual tendencies in contemporary art are laden with satirical messages by combining various idioms, slogans, and symbols. This is often associated with the contemporary spirit itself, where contemporary artwork always emphasizes the depth of ideas and concepts.

This research actually tries to examine descriptively how the consumerism discourse can be visualized in contemporary works, including how the visual approach, how the style of expression, and the social effects of the works. The objects of this research study are four contemporary works which are actually very well-known and even classified as iconic, including: (1) "Campbell's Soup Cans" by Andi warhol, (2) "Jesus Christ with Shopping Bags" by Banksy, (3) "I Shop Therefore I Am by Barbara Kruger, (4) "Super Supper" by Ron English. These works are considered the most representative of the discourse of consumerism, and have a very visual approach and concepts, therefore, they are able to express the discourse of consumerism clearly and uniquely.

1. Andy Warhol, “Campbell's Soup Cans”, 1962

Speaking about contemporary visual art without mentioning the name of Andy Warhol is indeed not complete. Warhol is an icon of pop art and versatile artists, he is an illustrator, writer, publisher, film director and painter, thanks to his intelligence he has succeeded in changing the world view through his ideas and works of art.

The 32 Campbell's Soup Cans is a work he produced in 1962, this work consists of thirty-two canvas measuring 51 x $41 \mathrm{~cm}$ made using semi-mechanical screen printing graphic techniques, a non-painting method which in that era was less appreciated and could cause polemic because of the frontal commercialization and impressed an insult to the methods and techniques in painting. But because something different was unique, it was built so that it finally marked the emergence of the pop art movement. This work was first exhibited at Gallery Feus, Los Angeles, on a dealer offer named Irving Blum. (https:// en.wikipedia.org/wiki/Campbell's_Soup_Cans)

Visually these thirty-two canvas panels are very similar, each one realistically depicting the iconic can of red and white Campbell soup. What distinguishes it is that each can reads a different taste, for example tomato soup, clam chowder, beef and so on, only one can

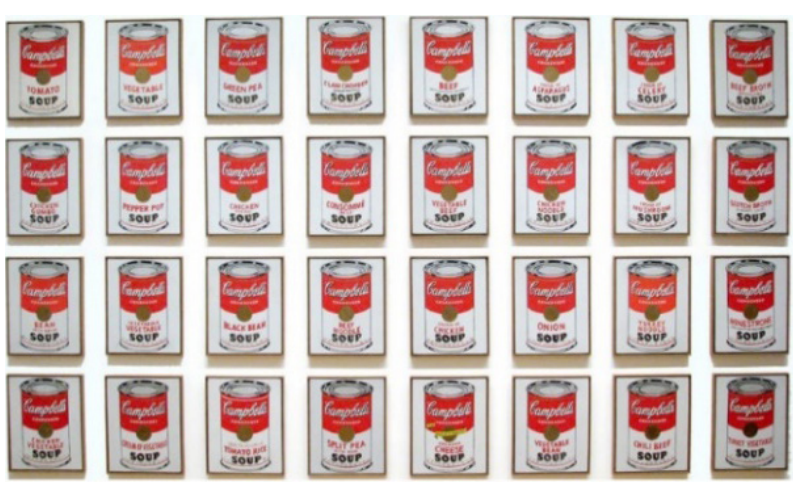

Figure 1. Andy Warhol's work entitled "Campbell's Soup Cans" consisting of 32 canvas panels with screen printing techniques. (Source: https://www.widewalls.ch/, accessed on Wednesday, October 31, 2018, at 15:56 GMT+7) 
of cheddar flavor is slightly different with an additional gold ribbon in the middle, the rest of the cans are really the same. Furthermore, this work is displayed on shelves just like a shopping aisle, an illustration of consumer culture and mass production that Andy Warhol displays in an intelligent way. (https://www.moma.org/ learn/moma_learning/andy-warhol-campbellssoup-cans-1962/)

The emphasis on the work of 32 Campbell's Soup Cans is actually on, (1) The description of the mass production Warhol displayed on the same 32 cans of soup, he describes himself (as a symbol of popular culture) is a machine that constantly produces passively. (2) With mass production through printing techniques to produce the same images, Warhol actually describes the loss of originality. (3) Indirectly this work places appreciator as consumers who shop.

2. Barbara Kruger, "I Shop Therefore I Am", 1987

The public may not really know who Barbara Kruger is, but people certainly know about the picture and slogan. Barbara Kruger is a feminist and drafter who is productive through black and white photography works with a specific caption, one of the most famous being the "I Shop Therefore I Am" or "Supreme" clothing brand. Kruger is an artist who

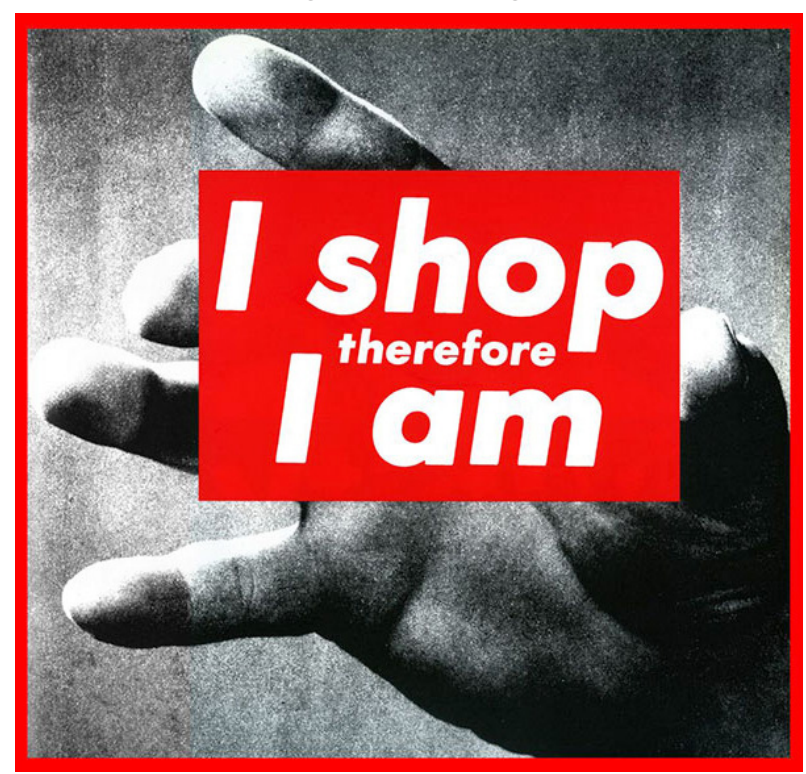

Figure 2. "I Shop Therefore I Am", black and white photographic work with red and white writing by Barbara Kruger (Source: https://www.widewalls.ch/, accessed on Wednesday, October 31, 2018, at 18:06 GMT+7) explores social issues through signs and language in her works. Most of her works are black and white photography with words that are firm or sad with thick Futura Bold Obllique or Helvetica Ultra Condensed fonts. The method of creating her work is digital imaging through computer and then printed in the form of images that are not infrequently in the size of billboards. (https://en.wikipedia.org/wiki/Barbara_Kruger)

Visually every work of Barbara Kruger focuses on the strength of her message on the firm words displayed. In the work of "I Shop Therefore I Am" there are actually two points that can be examined based on the viewpoint of consumerism. (1) The word I Shop Therefore I Am is actually a play on the slogan of philosopher Rene Descartes, where the original word is I Think Therefore I Am (Cogito Ergosum), which means that human existence is based on their intellect. The motto, according to Barbara Kruger, is not in accordance with the reality, which now through consumerism human existence is not based on intellect but on consumption. (2) This work visually also proves that aesthetics that are built in contemporary art do not necessarily emerge in real terms, but can appear in messages carried.

3. Banksy, "Jesus Christ with Shopping Bags", 2005

The public of contemporary visual art is certainly no stranger to the figure of Banksy, a phenomenal Street Artist from England who still hides his true identity. His anonymous identity and his controversy have made his name

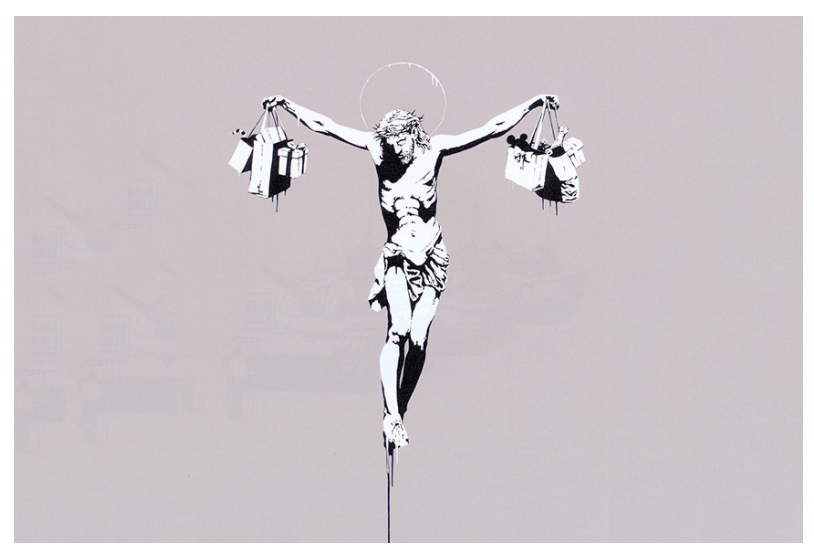

Figure 3. Banksy's work titled "Jesus Christ with Shopping Bags". (Source: https://www.widewalls.ch/, accessed on Wednesday, October 31, 2018, at 18:46 GMT+7) 
even more known, he has even been named as one of the con cultures of the UK. In the contemporary art world today, Banksy could be called the most phenomenal and controversial artist. How could he not? He even have just caused a stir in the public of fine art with a selfdestruction video of his own work which had just been sold at auction for 1.4 million USD, an interesting fact.

Visually the works of Banksy are always political and social with satirical epigram in cruel humor. Banksy often uses symbols, cultural icons, or the works of world artists for him to parodize, e.g. McDonald's figure, the photos of a child in the Vietnam War, and even Napoleon. The characteristics of Banksy's work are stencil techniques on walls, bridges and city streets all over the world, although some of their original works are also in the form of paintings, sculptures and installations. (https:// en.wikipedia.org/wiki/Banksy).

The work "Jesus Christ with Shopping Bags" was created at Christmas in 2005, with stencil and screen printing techniques measuring $70 \times 50 \mathrm{~cm}$ (https://www.graffitistreet.com). Visually this work displays an image that is actually very sensitive, he displays a Jesus Christ figure without a cross holding a shopping bag on his right and left hand, as if to illustrate that he was killed by consumption, not because of being crucified. In his shopping bag, some symbols are included, such as candy and Mickey Mouse, as implies that the Christmas celebration is always synonymous with the tradition of excessive consumption.

This work carries a very strong message, anyone will understand immediately without the need to explain what the concept is. Banksy seems to describe that consumption is the god of today's society. In this work, Banksy succeeded in using intelligent and precise visual language, he combined sensitive symbols in different real contexts. First, the figure of Jesus Christ expresses the divinity and trust of the people. Secondly, shopping goods along with the symbol of candy and Mickey Mouse to illustrate the trust in the community itself.
4. Ron English, "Super Supper”, 2010

Ron English is a contemporary American artist who is popular with his Pop Art style, cartoon characters, and visual exploration through advertisements and famous brands. Ron English is also known as a Street Artist in his POPaganda style, the approach he created to combine high culture and low culture, banging the contents of popular culture with historic artwork. Everything is illustrated through the visualization of popular culture mascots such as McDonald's, Mickey Mouse, superhero characters or characters of his own creation. Ron English combines various kinds of cultural icons to get the image and perception of consumer cultural discourse (https://en.wikipedia.org/ wiki/Ron_English_).

Visually, the first impression that appears in the works of Ron English is a very strong element of parody. The characteristics of Ron English's works seem to refer to the Pop Surrealism style, where he combines various cross-cultural icons and symbols to form a strange and exaggerated new image, funny but cynical and satirical. Visualization is a representation of inconvenience to existing reality, such as political, social and humanitarian discourse (Prabu, 2017: 41).

The "Super Supper" work is visually worked out in such a detail with a stunningly realistic style, interesting selection of figures, and typical Pop Art colors as if trapping the perception that this is actually the content being parodied. The

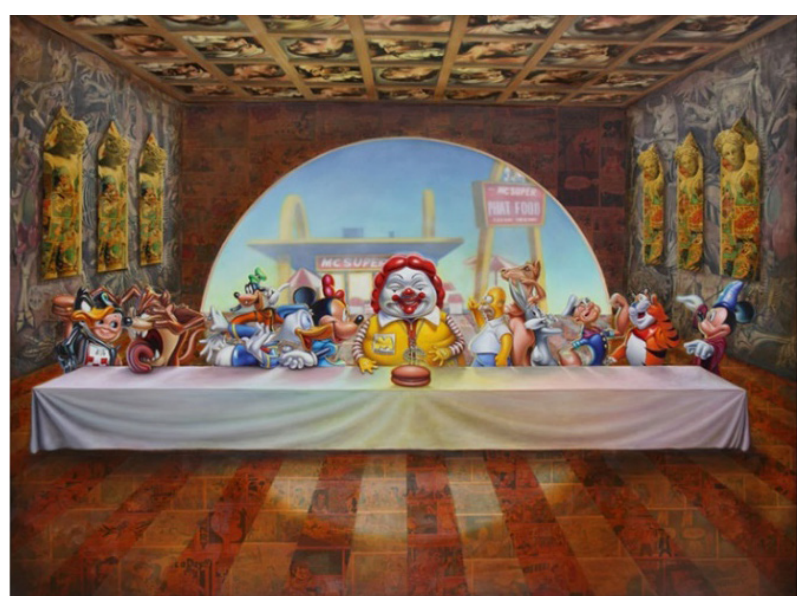

Figure 4. Ron English's work titled "Super Supper". (Source: https://www.widewalls.ch/, accessed on Sunday, November 4, 2018, 17: 14 GMT+7) 
original image of the image is the iconic mural painting "The Last Supper" by Leonardo Da Vinci, where the real figure is Jesus Christ at the banquet table. The setting was then replaced by Ron English with popular culture characters that were full of consumerism. Like the modified McDonalds' mascot and cartoon characters such as Mickey Mouse, Donald Duck, The Simpson and so on. The background image of McDonald's fast food restaurant and also a Hamburger on the table. McDonald's character is portrayed as fat man with mysterious laugh and expression facing a hamburger as if symbolizing the reality of consumerism built by fast food products. Ron English is genius to hint that society is now being treated to the reality of consumption through products and popular cultural contents.

\section{Ethical and Aesthetic Problems}

Based on the analysis of the four works, one strong characteristic can be seen, that is the existence of satire elements, criticism and constructed antics, some of which even display very sensitive visuals such as portrayal of Jesus Christ figures.

Ethical values cannot be completely ignored in life even in the art world, because after all works of art are manifestations of human interpretations that are still bound by social norms. The ethical problems of these works remain in the realm of the context of space and time, where in the reality of western society life it might be considered normal. However, if the work with this sensitive image is faced with conservatives or eastern societies, misunderstandings can occur and are considered severe harassment. Therefore, it is actually public perception that is tested in this regard, the public's maturity in reading the reality through the visual language of the works in the context of social criticism.

Apart from being a form of social criticism, these works can also be understood as a form of visual literacy for contemporary society. Apart from that, these works, aside from being works of art, are also a form of awareness of the reality of consumerism that has brought about changes in human life. These points can once again be reached if the public can understand the message of the work in the right context.

The next problem is posesthetics, posesthetics is a tendency in contemporary life, especially in the world of art about status and aesthetic assessment. Everything that was previously considered not aesthetic value, like something bad, disgusting, frightening and strange, is now precisely regarded as a part of aesthetics (Piliang, 2004: 20).

Contemporary art does offer its own strange, unique and interesting taste.

Aesthetics in contemporary visual art is no longer a public monopoly on understanding the beauty of works of art visually, furthermore the aesthetics of art is an analytical awareness of both the reality and metaphysical (Piliang, 2004: 150). In other words, contemporary aesthetics is trying to provide an understanding that beauty is something complex, it can be implicit, but actually has a deep message, and not only as something that is seen by the senses and the surface.

Therefore, the tendency towards posesthetics in the context of the art world is actually not wrong. Given that the shift in understanding is indeed based on the development of the times and the existing reality. What is important is that contemporary works can still be enjoyed and remain in the corridors of art and expression.

\section{Conclusion}

Based on the study and analysis above, it can be concluded that the discourse of consumerism is represented in these works representative through straightforward and symbolic visuals. Consumerism, which was initially abstract in the form of discourse and social symptoms can be clearly understood through a symbolic approach, therefore, the works become communicative.

The visual characteristics of the works are; (1) the tendency of style in these four works is Pop Art through various techniques ranging from digital photographs, screen printing, stencils and realistic painting techniques. (2) the use of various symbols and signs that are closely related to popular culture and consumerism such as McDonald's character, Mickey Mouse, consumer product packaging, 
consumption slogans, to religious symbols such as Jesus Christ and the last supper.

The style of expression in the four works is symbolic representative that is thick with elements of witty, satirical and sarcasm. Through this approach, the works try to redraw the discourse about consumerism through symbols of popular culture. Therefore, the clear impression and picture of the discourse of consumerism itself is achieved.

The four works above are some examples of contemporary art that are still attached to various kinds of contradictions. The strange visual form and sarcastic attachment are sensitive things. In the context of the art world, these works offer a new aesthetic approach, namely posesthetics, an aesthetic view that is inversely proportional to the existing aesthetic standard. In the broad social context, these works can cause ethical problems because the sarcastic visuals display sensitive images that overwhelm religious symbols.

\section{References}

\section{a. Journal Articles}

Dias Prabu, W. N. (2017). Imaji Pop Surealisme Figur Gendut Dalam Lukisan. Journal of Urban Societye Art, 4(1), 36-48. Retrieved from http://journal.isi.ac.id/index.php/JOUSA/ article/view/1489

Kusrini, K. (2015). Potret Diri Digital dalam Seni dan Budaya Visual. Journal of Urban Society's Arts, 2(2), 111-1222. Retrieved from http:// journal.isi.ac.id/index.php/JOUSA/article/ view/1448

Ramadhani, Cadensi. Citra. (2017). "Penyadara Berekspesi dalam Estetika Seni Rupa Kontemporer". Seminar Nasional Seni dan Desain: "Membangun Tradisi Inovasi (Melalui Riset Berbasis Praktik Seni dan Desain)"FBS Unesa, 28 Oktober 2017

\section{b. Books}

Djatiprambudi, Djuli. 2016. Seni Rupa Indonesia dalam Titik Simpang. Sidoarjo. Satukata Bookart Publisher.

Piliang, Yasraf. Amir. 2004. Posrealitas : Realitas Kebudayaan dalam Era Posmetafisika. Yogyakarta. Jalasutra.

Piliang, Yasraf. Amir. 2003. Hipersemiotika: Tafsir Cultural Studies atas Matinya Makna. Yogyakarta. Jalasutra.

Wicaksono, Singgih. Prio. 2018. Citra Budaya Konsumtif Sebagai Tema Penciptaan Karya Seni Kriya Kayu. Universitas Negeri Surabaya

\section{c. Websites}

Banksy. https://en.wikipedia.org/wiki/Banksy. (Accessed on Wednesday, November 07, 2018, at 21:23 GMT+7)

Barbara Kruber. https://en.wikipedia.org/wiki/ Barbara_Kruger. (Accessed on Wednesday, November 07, 2018, at 21:23 GMT+7)

Campbell's Soup Cans. https://en.wikipedia.org/ wiki/Campbell's_Soup_Cans. (Accessed on Wednesday, November 07, 2018, at 21:16 GMT+7)

Campbell's Soup Cans. https:/www.moma.org/ learn/moma_learning/andy-warhol-campbells-soup-cans-1962/. (Accessed on Wednesday, November 07, 2018, at 21:20 GMT+7)

Cordic, Agie. Consumer Culture Expressed Through 10 Contemporary Art Pieces. 2015. https:// www.widewalls.ch/consumerist-cultureart-10-artworks/. (Accessed on Wednesday, October 31, 2018, at 15:56 GMT+7)

Jesus Christ with Shopping Bags. https://www. graffitistreet.com. (Accessed on Wednesday, October 31, 2018, at 16:12 GMT+7)

Ron English. https://en.wikipedia.org/wiki/Ron_ English. (Accessed on Wednesday, November 07, 2018, at 21:56 GMT+7) 